\title{
Article \\ Experimental Study of the Thermal and Dynamic Behaviors of Polypropylene Fiber-Reinforced Concrete
}

\author{
Liu Lei ${ }^{1}$, Lizhe Dong ${ }^{1}$, Huaming An ${ }^{1,2, *}$, Yuqing Fan ${ }^{3}$ and Ya Wang ${ }^{1}$ \\ 1 Faculty of Land Resource Engineering, Kunming University of Science and Technology, \\ Kunming 650093, China; kgliulei@kust.edu.cn (L.L.); lizhedong@stu.kust.edu.cn (L.D.); \\ wangya@stu.kust.edu.cn (Y.W.) \\ 2 Faulty of Public Security and Emergency Management, Kunming University of Science and Technology, \\ Kunming 650093, China \\ 3 School of Mining Engineering, Guizhou University of Engineering Science, Bijie 551700, China; \\ yuqingfanfan@gmail.com \\ * Correspondence: huaming.an@kust.edu.cn
}

Citation: Lei, L.; Dong, L.; An, H.; Fan, Y.; Wang, Y. Experimental Study of the Thermal and Dynamic Behaviors of Polypropylene Fiber-Reinforced Concrete. Appl. Sci. 2021, 11, 10757. https://doi.org/ 10.3390/app112210757

Academic Editor: Chao-Wei Tang

Received: 6 October 2021

Accepted: 8 November 2021

Published: 15 November 2021

Publisher's Note: MDPI stays neutral with regard to jurisdictional claims in published maps and institutional affiliations.

Copyright: (c) 2021 by the authors. Licensee MDPI, Basel, Switzerland. This article is an open access article distributed under the terms and conditions of the Creative Commons Attribution (CC BY) license (https:// creativecommons.org/licenses/by/ $4.0 /)$.

\begin{abstract}
The wide use of high-performance concrete (HPC) makes it essential to study its dynamic and thermal behavior. In this study, polypropylene fiber-reinforced high-performance concrete was developed and a series of tests were carried out to obtain its mechanical and thermal properties. Since high-strength HPC has previously been studied intensively, only low-strength HPC-i.e., C30, C40, and C50-was studied in this research. The split Hopkinson pressure bar (SHPB) was employed to carry out the dynamic tests of the HPC under various loading rates and the principles of the SHPB were introduced in detail. Then, the polypropylene fiber-reinforced HPCs were heated to various high temperatures and measures were taken to keep the temperatures relatively constant. It was found that at temperatures lower than $100^{\circ} \mathrm{C}$, the specimen could still be kept in its entirety, although many fractures were produced in the HPC specimen under dynamic loading conditions. However, it was found that at temperatures higher than $200{ }^{\circ} \mathrm{C}$, all the HPC samples were smashed into fragments. In addition, the HPC's compressive strength was found to be significantly influenced by the temperature. At temperatures lower than $300^{\circ} \mathrm{C}$, the $\mathrm{HPC}^{\prime}$ s compressive strength was found to increase with increases in temperature. At temperatures higher than $300^{\circ} \mathrm{C}$, the $\mathrm{HPC}^{\prime} \mathrm{s}$ compressive strength was found to decrease with increases in temperature.
\end{abstract}

Keywords: polypropylene fiber-reinforced concrete; dynamic behaviors; high temperature; split Hopkinson pressure bar (SHPB)

\section{Introduction}

In recent decades, society has developed faster than ever before in history. The rapid development of society has greatly increased the need for geo-structures, such as tunneling, embankments, bridges, shafts, slopes, and all kinds of buildings for both living and working in. Meanwhile, accidents have occurred from time to time and have caused geo-structures to experience dynamic loading. In some cases, geo-structures have been subjected to both dynamic loading and high temperatures. As concrete is the most widely used building material for geo-structures [1-3], the dynamic and thermal behaviors of concrete are essential to the stability and durability of geo-structures [4-7]. As concrete has a low ductility and is very weak in tension, fiber-reinforced concrete has been developed and is employed in many geo-structures [4,8-10]. In addition, as the majority of geo-structure accidents-e.g., failures and collapses-are related to fractures produced due to static or dynamic loading, it is important to study the dynamic fracture mechanism of concrete.

The split Hopkinson pressure bar (SHPB) might be the most used testing equipment [11-15] for the study of the dynamic behavior of concrete and rock-like brittle materials. Hopkinson (1941) developed the SHPB by using a pressure bar to test the pulse 
waveform; then, it was employed to measure the mechanical properties of rock under dynamic loads [16]. The SHPB can be used to study rock mechanics at strain rates between $10^{1} \sim 10^{4} \mathrm{~S}^{-1}$. Many dynamic tests of concrete and rock-like materials have been conducted by a number of researchers using the SHPB. Among those tests, the uniaxial compression test, the Brazilian disk test, and the semi-disc with the pre-fabricated crack test are recommend by the International Society of Rock Mechanics as standard dynamic experiment methods. Tedesco et al. (1994) conducted an impact test on cement and studied the influence of the loading rate on the cement strength using the split Hopkinson pressure bar [17]. In addition, Galvez et al. (1997) also used the split Hopkinson pressure bar to study the dynamic behavior of ceramic materials and concluded that the loading rates influenced the tensile strength of the materials significantly [18]. Sukontasukkul, Nimityongskul et al. (2004) found that specimens subjected to impact loading were found to suffer greater damage than those subjected to static loading [19]. Zhao (2000) conducted dynamic uniaxial and triaxial compressive strength tests and concluded that compressive strength increases with an increased loading rate [20]. Zhang (2000) also conducted a dynamic uniaxial compressive strength test and concluded that the number of cracks increases with an increasing loading rate [21]. Besides those researchers mentioned above, many researchers have reached almost the same conclusion: the loading rate significantly influences the behavior of brittle materials [19-26]. The thermal behaviors of brittle materials have been extensively studied. Li Xibing et al. (2010) studied the dynamic and thermal behaviors of siltstone and found that, in the range of $20-100{ }^{\circ} \mathrm{C}$, the compressive strength increases with increases in temperature, while it decreases with increases in temperature when the temperature is higher than $100{ }^{\circ} \mathrm{C}$ [27]. Yin, Li et al. (2013) studied the properties of granite under dynamic loading and higher-temperature conditions [28]. They found that the peak strain increased with the increase in temperature, while the strength of the granite decreased with the increase in temperature [28]. Xu and Liu (2013) carried out compression experiments with marble and found that when the temperature rises to $800^{\circ} \mathrm{C}$, the peak strength of marble becomes less obvious with changes in the loading rate.

To improve the stiffness of concrete, fiber-reinforced concrete was developed to increase its strength and ductility. The fibers added to the concrete can significantly influence the performance of the fiber-reinforced concrete when exposed to loadings and high temperatures [12-15]. Steel fiber, glass fiber, polymer fiber, and basalt fiber are the most commonly used materials for the reinforcement of concrete [29-33]. Different properties can be introduced by different types of reinforcing fibers [34]. For example, the addition of steel fiber or basalt fiber could improve the concrete's performance, such as its tensile strength, strain capacity, toughness, energy absorption capacity, and so on [35,36]. Carbon fiber can improve the electrical conductivity, pressure sensitivity, and magnetic sensitivity of concrete [37,38]. Compared with normal concrete, fiber-reinforced concrete exhibits a high compressive and tensile strength $[39,40]$, high fracture toughness [41,42], and high impact resistance [43-45]. Additionally, due to the superior material properties of fiberreinforced concrete, it has been widely used in many engineering projects. At present, steel fiber is the most commonly used fiber to add to concrete due to its excellent structural properties [46]. However, the durability properties, particularly the corrosion of steelfiber-reinforced concrete, are a significant drawback that increases the importance of other types of fibers [47]. However, polypropylene-fiber-reinforced concrete can overcome the drawbacks of steel-fiber-reinforced concrete.

Therefore, research about adding polypropylene fibers to concrete has developed rapidly in recent years $[48,49]$. As polypropylene is a low-cost material, its addition not only makes concrete more durable, but polypropylene fiber-reinforced concrete is also more economical than other fiber-reinforced concrete [48]. Moreover, polypropylene fiber has a low melting point, so when polypropylene-fiber-reinforced concrete is heated to a high temperature, this fiber would melt and provide pathways for water vaporization. Because of the decrease in inner vapor pressure, the microstructure of the concrete is 
protected [34]. Meanwhile, after heating, the spalling resistance of the concrete could be improved by polypropylene fiber [50,51].

Concrete is a kind of non-uniform composite material that is widely used in construction, water conservancy, hydropower, national defense, and other important projects. Due to the different ratios of raw materials and additives, the mechanical and thermal properties of concrete differ under the effect of high temperatures as a series of physical and chemical changes occur inside the concrete. In recent years, many scholars have studied the influence of high temperatures on the dynamic and static properties of concrete and conducted a large number of basic tests, achieving many significant research results. However, these experimental studies mainly focus on ordinary concrete and high-strength performance concrete.

However, in practical engineering applications, concrete with a strength grade of C20 to $\mathrm{C} 50$ are more widely used. There are few studies on high-performance concrete with medium- and low-strength grades-i.e., a strength grade of C20 to C50, especially under the condition of dynamic loading after being heated to a high temperature. Thus, this research focuses on low-strength HPC.

In this study, polypropylene fiber-reinforced high-performance concrete (HPC) was developed and three different strength grades of concrete were made for studying the thermal and dynamic behavior of the polypropylene fiber-reinforced high-performance concrete.

\section{Materials and Methods}

\subsection{Test Material}

In this research, normal concrete and high-performance concrete (HPC) with strength grades from C30 to C50 were made to study the dynamic and thermal behavior of HPC and to compare the mechanical properties between the normal concrete and the HPC. The specimens were made according to the specifications for the mix proportion design of ordinary concrete JGJ55-2011 [52], the standard for testing mechanical properties in ordinary concrete [53], and the technical specification for the application of high-performance concrete [54].

P.O. 42.5 ordinary Portland cement produced by Yunnan Yiliang Hongshi Cement Co., LTD (Kunming, China), with a density of $2908 \mathrm{~kg} / \mathrm{m}^{3}$ was selected as one of the main components for both the normal concrete and the HPC. Table 1 summarizes the chemical composition of Portland cement while Table 2 illustrates the main performance parameters.

In this research, high-quality grade II fly ash produced by Yunnan Power Plant (Kunming, China), with a density of $2098 \mathrm{~kg} / \mathrm{m}^{3}$ was used. The main chemical components are shown in Table 3.

Table 1. Chemical composition of Portland cement.

\begin{tabular}{ccccccc}
\hline $\begin{array}{c}\text { Chemical } \\
\text { Composition }\end{array}$ & $\mathrm{SiO}_{2}$ & $\mathrm{CaO}$ & $\mathrm{MgO}$ & $\mathrm{Fe}_{2} \mathrm{O}_{3}$ & $\mathrm{NaO}$ & $\mathrm{K}_{2} \mathrm{O}$ \\
\hline$\%$ & 20.7 & 64.0 & 1.82 & 4.41 & 0.2 & 1.2 \\
\hline
\end{tabular}

Table 2. Physical properties of ordinary Portland cement.

\begin{tabular}{ccccccc}
\hline Cement Type & \multicolumn{2}{c}{ Setting Time (min) } & \multicolumn{2}{c}{ Compressive Strength (MPa) } & \multicolumn{2}{c}{ Flexural Strength (Mpa) } \\
\hline & Initial Setting & Final Setting & 3 day & 28 day & 3 day & 28 day \\
\hline P.O42.5 & 180 & 240 & 20.7 & 45.1 & 6.1 & 10.2 \\
\hline
\end{tabular}

Table 3. Main chemical constituents of fly ash.

\begin{tabular}{cccccccc}
\hline $\begin{array}{c}\text { Chemical } \\
\text { Composition }\end{array}$ & $\mathrm{SiO}_{2}$ & $\mathrm{Al}_{2} \mathrm{O}_{3}$ & $\mathrm{CaO}$ & $\mathrm{MgO}$ & $\mathrm{SO}_{3}$ & $\mathrm{Fe}_{2} \mathrm{O}_{3}$ & $\mathrm{Na}_{2} \mathrm{O}$ \\
\hline$\%$ & 40.2 & 14.5 & 1.9 & 1.5 & 1.6 & 1.7 & 1.2 \\
\hline
\end{tabular}


The addition of polypropylene fiber to high-performance concrete could significantly increase the tensile strength, fatigue strength, and bending strength of the concrete. In addition, the early crack resistance of concrete could be improved by the addition of polypropylene fiber. The main performance parameters of the polypropylene fiber that was used in this test are shown in Table 4.

Table 4. Main performance parameters of polypropylene fiber.

\begin{tabular}{cccc}
\hline Characteristics & Parameters & Characteristics & Parameters \\
\hline Color & White or faint yellow & Shape & Monofilament bundle \\
\hline Density & $1.18\left(\mathrm{~g} / \mathrm{cm}^{3}\right)$ & Equivalent diameter & $9-30 \mathrm{um}$ \\
\hline Length & $3-9(\mathrm{~mm})$ & Melting point & $220\left({ }^{\circ} \mathrm{C}\right)$ \\
\hline Acid resistance & Excellent & Alkali resistance & Excellent \\
\hline Tensile strength & $\geq 900 \mathrm{Mpa}$ & Elongation at break & $\geq 15-25(\%)$ \\
\hline Elastic modulus & $\geq 13,000 \mathrm{Mpa}$ & Water absorption & Water resistance \\
\hline
\end{tabular}

Besides cement and fly ash, many other components and their ratios for normal concrete are listed in Table 5. In the grade list of Table 5, N indicates normal concrete and B indicates normal concrete with polypropylene fiber.

Table 6 gives the main component ratios for the high-performance concrete. In the grade list, $\mathrm{H}$ indicates high-performance concrete, while B indicates high-performance concrete with polypropylene fibers added.

Table 5. Ordinary concrete mix ratio $\left(\mathrm{kg} / \mathrm{m}^{3}\right)$.

\begin{tabular}{cccccccc}
\hline Grade & Water & Cement & River Sand & Stone & Polypropylene Fiber & Water-Binder Ratio & Sand Ratio \\
\hline N-C30 & 215 & 360 & 693 & 1132 & - & 0.60 & $38 \%$ \\
\hline N-C40 & 215 & 450 & 659 & 1076 & - & 0.48 & 0.40 \\
\hline N-C50 & 215 & 540 & 625 & 1020 & - & 0.60 & $38 \%$ \\
\hline N-C30-B & 215 & 360 & 693 & 1132 & 1 & 0.48 & $38 \%$ \\
\hline N-C40-B & 215 & 450 & 659 & 1076 & 1 & 0.40 & $38 \%$ \\
\hline N-C50-B & 215 & 540 & 625 & 1020 & 1 & $38 \%$ \\
\hline
\end{tabular}

Table 6. High-performance concrete mix ratio $\left(\mathrm{kg} / \mathrm{m}^{3}\right)$.

\begin{tabular}{|c|c|c|c|c|c|c|c|c|c|c|}
\hline Grade & Water & Cement & Fly Ash & $\begin{array}{l}\text { Silica } \\
\text { Fume }\end{array}$ & $\begin{array}{l}\text { River } \\
\text { Sand }\end{array}$ & Stone & $\begin{array}{c}\text { Polypropylene } \\
\text { Fiber }\end{array}$ & $\begin{array}{c}\text { Water } \\
\text { Reducing Agent }\end{array}$ & $\begin{array}{l}\text { Water-Binder } \\
\text { Ratio }\end{array}$ & $\begin{array}{l}\text { Sand } \\
\text { Ratio }\end{array}$ \\
\hline H-C30 & 160 & 234 & 108 & 18 & 714 & 1166 & 1 & 7.2 & 0.44 & $38 \%$ \\
\hline H-C40 & 160 & 292.5 & 135 & 22.5 & 680 & 1110 & 1 & 9 & 0.36 & $38 \%$ \\
\hline H-C50 & 160 & 351 & 162 & 27 & 646 & 1054 & 1 & 10.8 & 0.30 & $38 \%$ \\
\hline H-C $30-B$ & 160 & 234 & 108 & 18 & 714 & 1166 & - & 7.2 & 0.44 & $38 \%$ \\
\hline H-C $40-\mathrm{B}$ & 160 & 292.5 & 135 & 22.5 & 680 & 1110 & - & 9 & 0.36 & $38 \%$ \\
\hline H-C50-B & 160 & 351 & 162 & 27 & 646 & 1054 & - & 10.8 & 0.30 & $38 \%$ \\
\hline
\end{tabular}

\subsection{Test Equipment}

A camber-type electric resistance furnace, as illustrated in Figure 1a, was employed to heat the concrete samples to a specific temperature in order to test the dynamic and thermal behavior of the ordinary concrete and the HPC under various loading rates and after various high-temperature treatments. The temperatures used in this research for the concrete samples were set as indoor temperature $\left(25^{\circ} \mathrm{C}\right), 100{ }^{\circ} \mathrm{C}, 200^{\circ} \mathrm{C}, 400^{\circ} \mathrm{C}, 600^{\circ} \mathrm{C}$, and $800^{\circ} \mathrm{C}$. Figure $1 \mathrm{~b}$ shows the equipment used for maintaining a constant temperature for the specimens. As illustrated in Figure 2a, the TAW-2000 computer-controlled automatic 
pressure-testing machine was used to carry out the static test for the normal concrete and the HPC. Figure $2 b, c$ shows the specimens placed in the machine during testing.

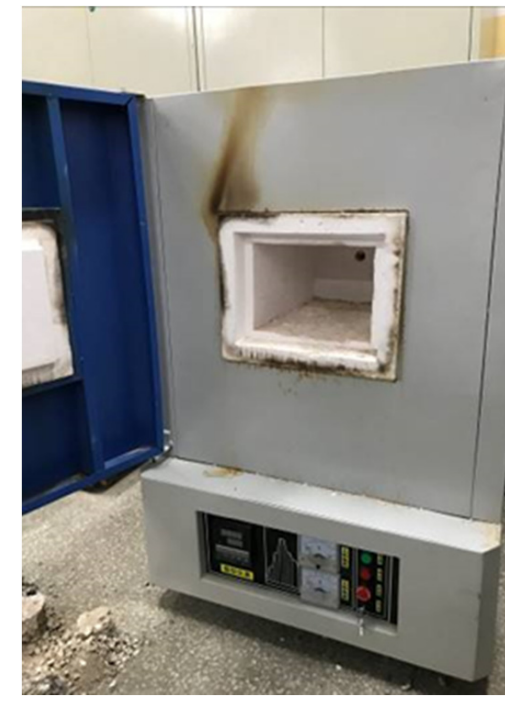

(a)

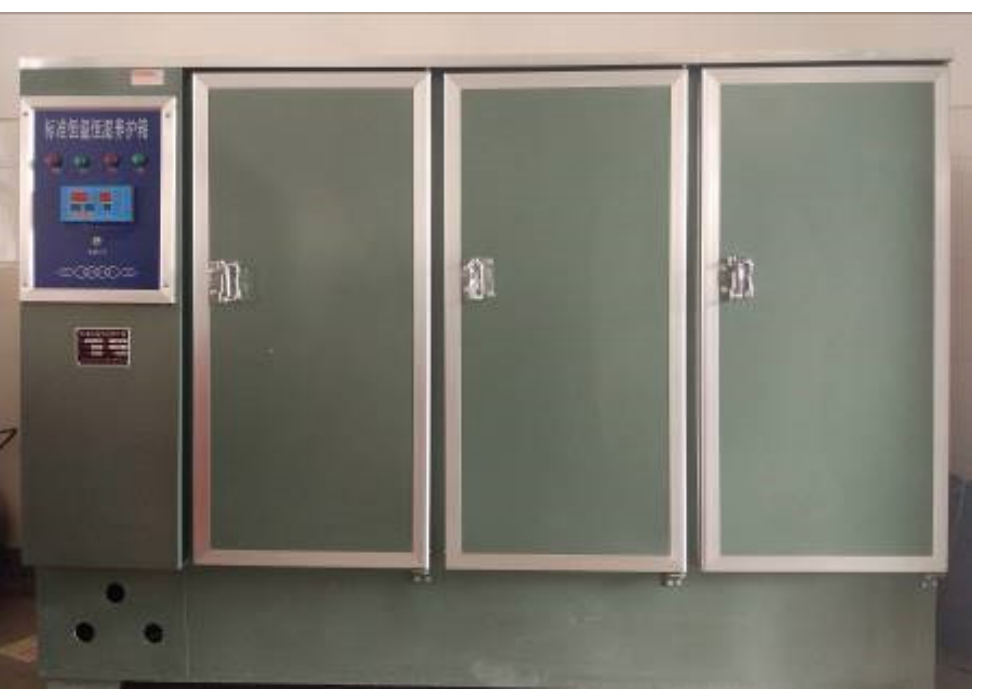

(b)

Figure 1. Equipment used for heating concrete specimens (a) and keeping the temperature constant (b).

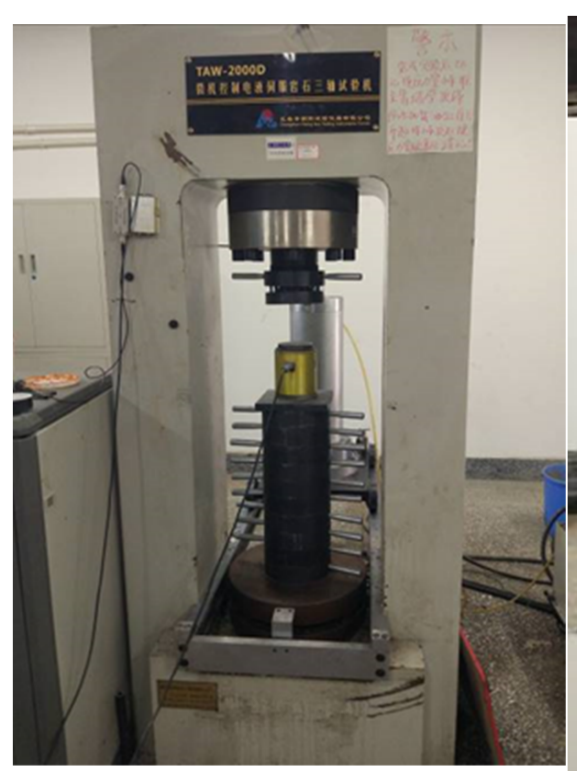

(a)

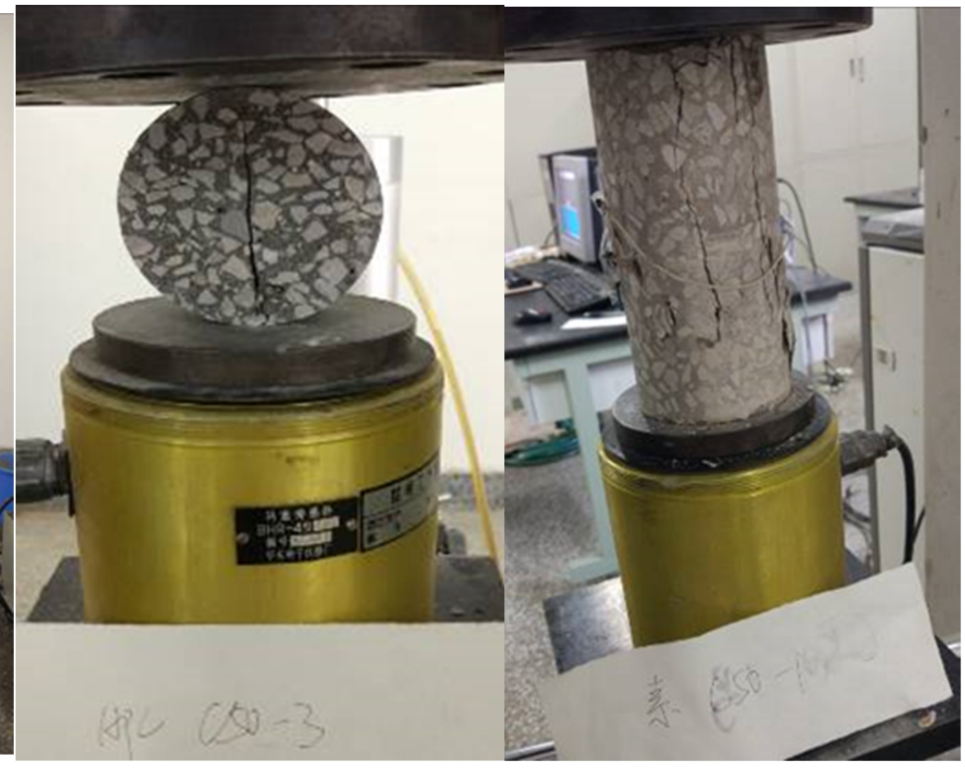

(b) (c)

Figure 2. TAW-2000 computer-controlled automatic pressure-testing machine (a) and working conditions (b,c).

As illustrated in Figure 3, the split Hopkinson pressure bar (SHPB) was adopted to carry out the dynamic test for the normal concrete and the HPC, and comprised a gas gun, a striker, an incident bar, a transmission bar, and a dynamic strain meter system. To illustrate how the SHPB works, a schematic of the SHPB is given in Figure 4. During the test, the gas gun was used to accelerate the striker bar to impact on one end of the incident bar. Then, the dynamic compressive strain wave produced propagates towards the other end of the incident bar. During the interaction of the incident bar and the sample, some part of the compressive wave is reflected, while the remaining part of the wave propagates towards the specimen. As the transmitted compressive strain wave reaches the interface of the specimen and the transmission bar, the disk is subjected to dynamic loading. 


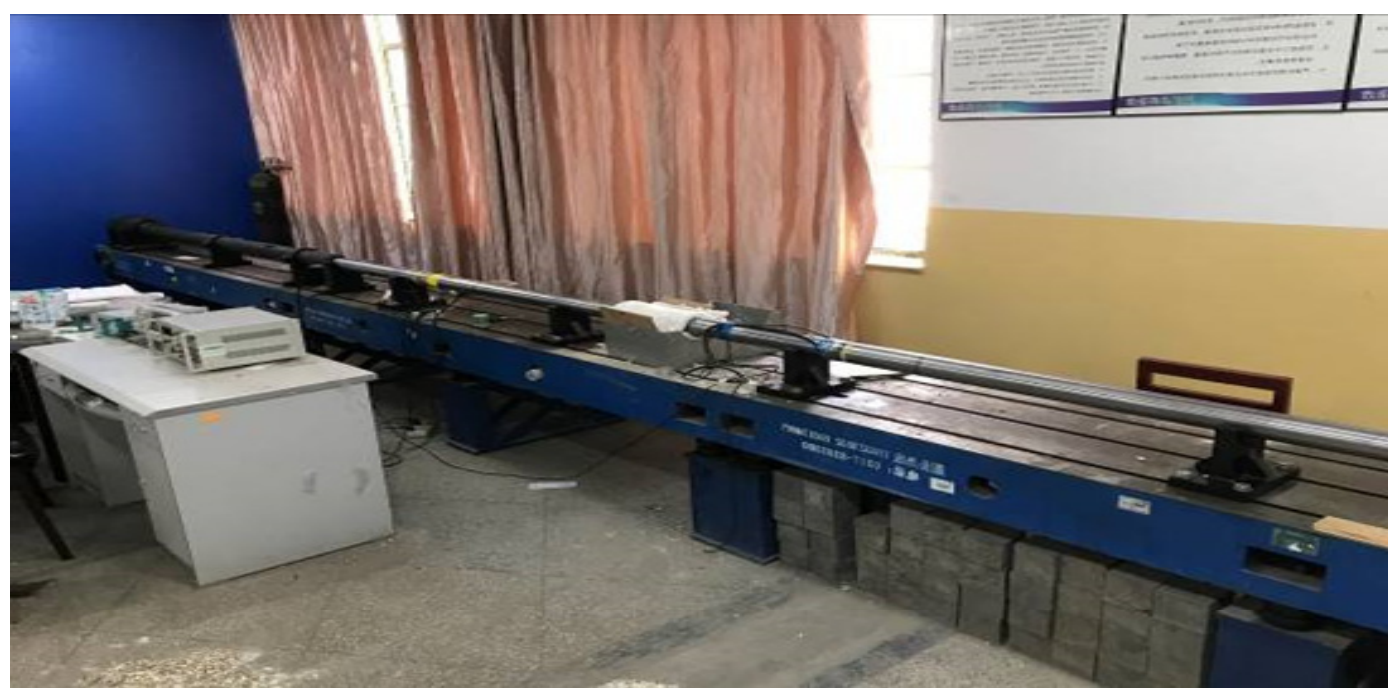

Figure 3. Split Hopkinson pressure bar (SHPB) system.

\subsection{Principles of Split Hopkinson Pressure Bar (SHPB)}

Figure 5 shows a diagram of the Hopkinson pressure bar during the dynamic test in order to illustrate the principle of the SHPB during HPC dynamic testing. Many researchers have explained the principles of the SHPB during the test in terms of mathematics [55,56]. In the following paragraphs, the principles of the split Hopkinson pressure bar (SHPB) are explained in terms of wave propagation based on previous research [5,55-57].

When the striker bar hits the incident bar, a compressive stress pulse wave of approximately one-dimensional propagation is generated in the incident bar. During the test, the compressive stress wave in the incident bar will propagate to the interface (the 1-1 interface in Figure 5). Some of the compressive stress waves can continue to propagate into the concrete samples, while the rest of the compressive stress waves will be reflected into the incident bar. As the compressive stress waves in the concrete sample reach the contact surface of the sample and the transmission bar (the 2-2 interface in Figure 5), the stress waves will partly be reflected back to the concrete sample and partly transmitted into the transmission bar, as happened in the 1-1 interface. As the compressive stress waves are reflected back and forth three to six times through the 1-1 and 2-2 interfaces in the rock sample, the stress equilibration is established in the rock sample.

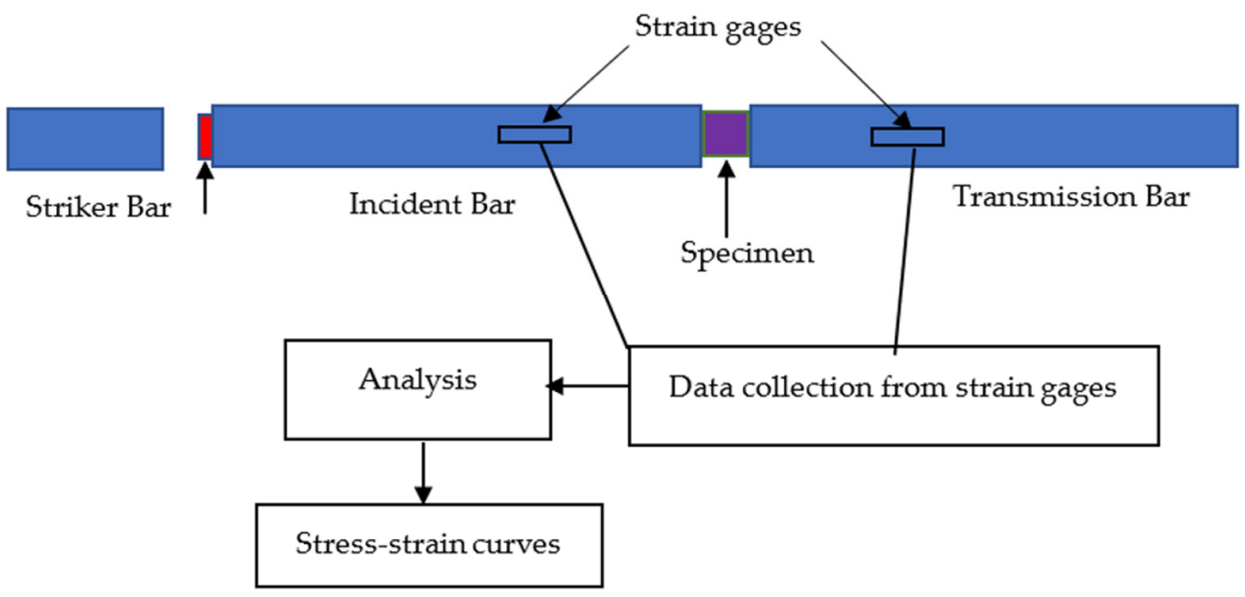

Figure 4. Schematic of conventional split Hopkinson pressure bar (SHPB) adapted from [57]. 


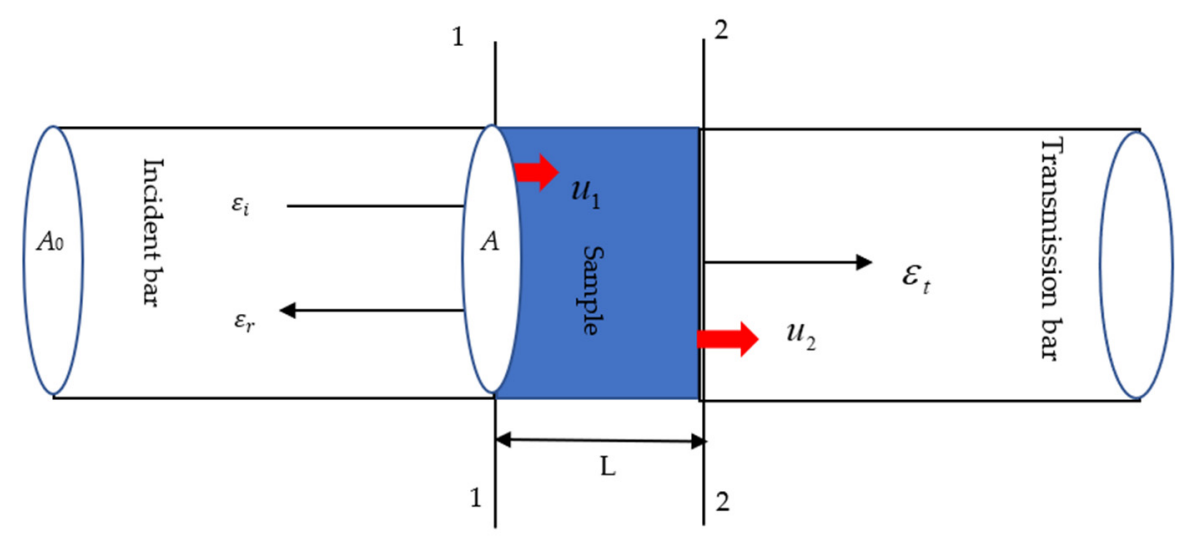

Figure 5. Schematic diagram of rock sample under impact by SHPB adapted from [57].

As illustrated in Figure 3, the cross-sectional area of the incident bar and the transmission bar is $A_{0}$, while the cross-sectional area and length of the concrete sample are $A$ and $L$, respectively. The stress at the interface of 1-1 and interface of 2-2 is $\sigma_{1}(t)$ and $\sigma_{2}(t)$, respectively. $C_{0}$ and $E_{0}$ indicate the wave velocity and the elastic modulus, respectively, of the incident bar and the transmission bar. $\varepsilon_{i}$ and $\varepsilon_{r}$ indicate the incident wave and the reflected wave in the incident bar. The transmission wave in the transmission rod is $\varepsilon_{t}$. $u_{1}$ and $u_{2}$ indicate the mass velocities at the interface of specimen 1-1 and the interface of specimen 2-2, respectively. If the average strain in the specimen is $\varepsilon$, the strain rate is $\dot{\varepsilon}$. Based on the continuity condition of the displacement and the one-dimensional stress hypothesis of stress waves, the following equations can be constructed.

Velocity at the interface 1-1:

$$
u_{1}(t)=C_{0}\left[\varepsilon_{i}(t)-\varepsilon_{r}(t)\right]
$$

Velocity at the interface 2-2:

$$
u_{2}(t)=C_{0} \varepsilon_{t}(t)
$$

Strain rate in the rock sample:

$$
\dot{\varepsilon}(t)=\frac{u_{1}(t)-u_{2}(t)}{L}=\frac{C_{0}}{L}\left[\varepsilon_{i}(t)-\varepsilon_{r}(t)-\varepsilon_{t}(t)\right]
$$

Strain during time $t$ :

$$
\varepsilon(t)=\frac{\mathcal{c}_{0}}{L} \int_{0}^{t}\left[\varepsilon_{i}(t)-\varepsilon_{r}(t)-\varepsilon_{t}(t)\right] d t
$$

Stress at 1-1 interface:

$$
A \sigma_{1}(t)=A_{0} E_{0}\left[\varepsilon_{i}(t)+\varepsilon_{r}(t)\right]
$$

Stress at 1-1 interface:

$$
A \sigma_{2}(t)=A_{0} E_{0} \varepsilon_{t}
$$

Average stress in specimen:

$$
\sigma(t)=\frac{\left[\sigma_{1}(t)+\sigma_{2}(t)\right]}{2}=\frac{A_{0} E_{0}}{2 A}\left[\varepsilon_{i}(t)+\varepsilon_{r}(t)+\varepsilon_{t}(t)\right]
$$

When the stress pulse wave propagates to and fro several times in the specimen, a stress equilibrium state is established. In this case, the three strains are equal, as shown in Equation (8).

$$
\varepsilon_{i}+\varepsilon_{r}=\varepsilon_{t}
$$


Thus, by substituting Equation (8) into Equations (1)-(7), the following equations can be achieved:

$$
\begin{gathered}
\dot{\varepsilon}(t)=-\frac{2 C_{0}}{L} \varepsilon_{r}(t) \\
\varepsilon(t)=-\frac{2 C_{0}}{L} \int_{0}^{t} \varepsilon_{r}(t) d t \\
\sigma(t)=\frac{A_{0} E_{0}}{A} \varepsilon_{t}(t)
\end{gathered}
$$

Equations (8) and (9) can be used to calculate the stress, strain, and strain rate in this research.

\section{Test Results}

\subsection{High-Performance Concrete Insulation Measures}

During the high-temperature SHPB test of high-performance concrete, asbestoswrapped specimens were loaded on the test bench, as shown in Figure 6, to reduce the heat loss of the concrete specimens to the surrounding air and to keep the test specimens in a relatively sealed environment. Thus, the concrete specimen can be kept at a constant temperature during the tests.
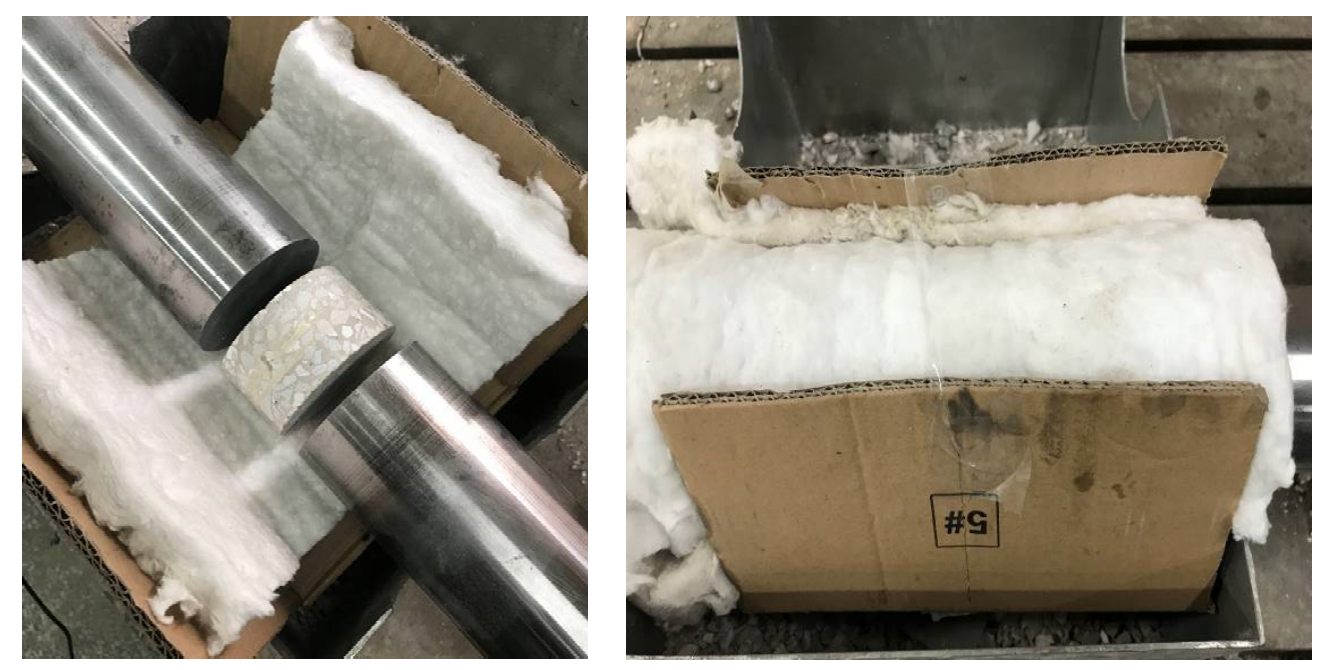

Figure 6. Insulation measures for the HPC during SHPB tests.

\subsection{SHPB Test Results}

Three kinds of ordinary concrete and high-performance concrete with different strength grades, C30, C40, and C50, were used as samples for the dynamic tests using SHPB. The normal concrete was only tested at room temperature, while the high-performance concrete was divided into nine temperature gradients: room temperature $\left(25^{\circ} \mathrm{C}\right), 100^{\circ} \mathrm{C}, 200^{\circ} \mathrm{C}$, $300{ }^{\circ} \mathrm{C}, 400{ }^{\circ} \mathrm{C}, 500{ }^{\circ} \mathrm{C}, 600^{\circ} \mathrm{C}, 700{ }^{\circ} \mathrm{C}$, and $800{ }^{\circ} \mathrm{C}$. There were also at four pressures of $0.4 \mathrm{MPa}, 0.6 \mathrm{MPa}, 0.8 \mathrm{MPa}$, and 1.2 $\mathrm{MPa}$ for the gas gun. V1, V2, V3, and V4 are used to indicate four speeds of the striker corresponding to the four gas gun pressure settings.

Figure 7 shows the test results of the HPC specimens at the same pressure $(1.2 \mathrm{Mpa})$ with various high-temperature treatments-i.e., $100^{\circ} \mathrm{C}, 200{ }^{\circ} \mathrm{C}, 300{ }^{\circ} \mathrm{C}, 400{ }^{\circ} \mathrm{C}, 500{ }^{\circ} \mathrm{C}$, $600{ }^{\circ} \mathrm{C}, 700^{\circ} \mathrm{C}$, and $800^{\circ} \mathrm{C}$-from the first picture to the last one. 

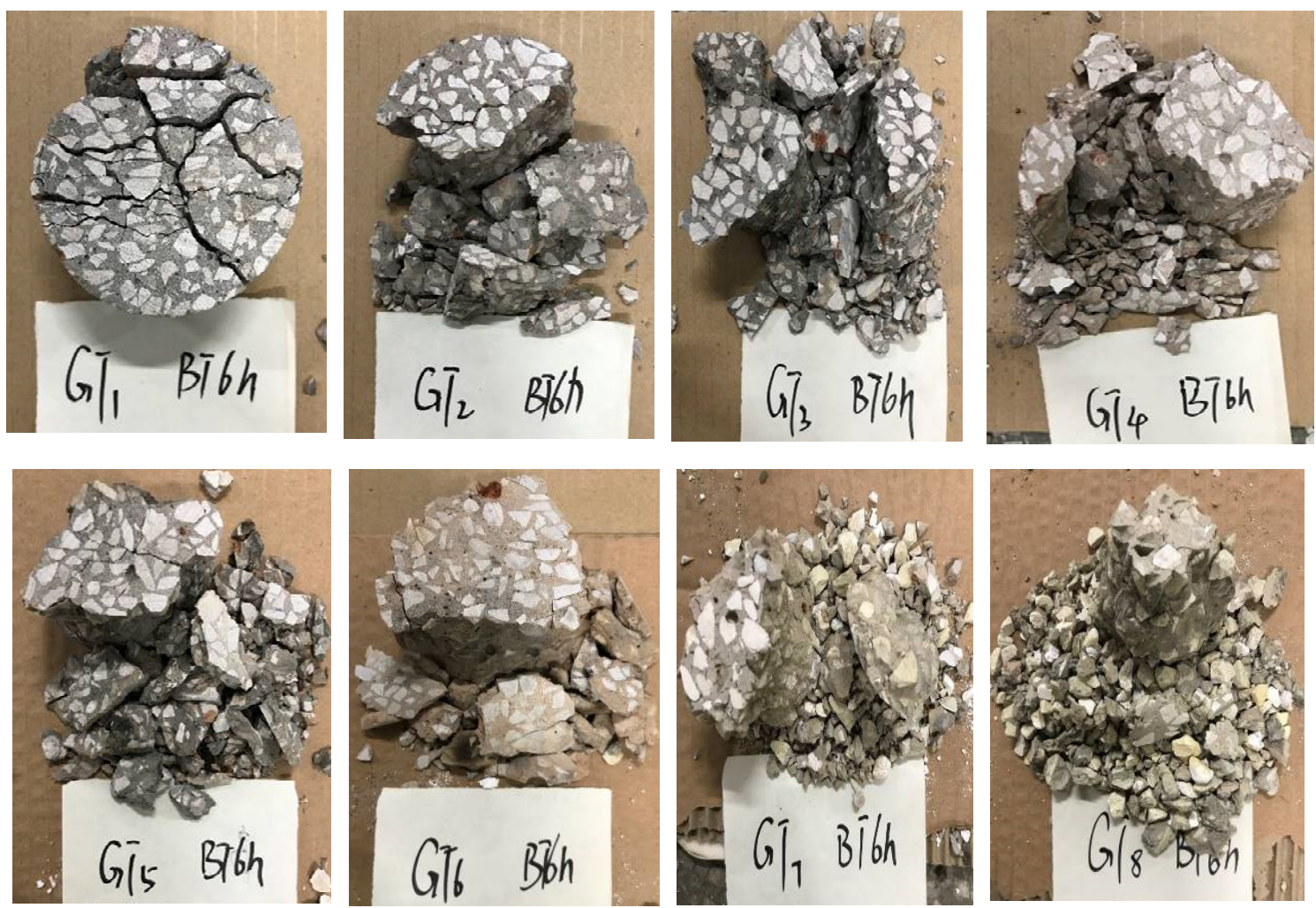

Figure 7. Fracture patterns of HPC specimens after impacts at different temperatures.

It can be seen from the first picture-i.e., the specimen that received a $100{ }^{\circ} \mathrm{C}$ temperature treatment-that many fractures were produced. However, it was not smashed into fragments. For the rest of the test results, the size of the fragments decreases as the temperature increases.

Since the melting point of the polypropylene fiber in the admixture is $165^{\circ} \mathrm{C}$, the test sample at $100{ }^{\circ} \mathrm{C}$ becomes "cracked" without spreading, while the test samples at $200{ }^{\circ} \mathrm{C}$ and $300{ }^{\circ} \mathrm{C}$ appear to fracture into "large blocks" after impact. The distribution gradually becomes "crushed" as the temperature rises.

\section{Discussion}

\subsection{Effect of the Loading Rate on Dynamic HPC Strength}

High-performance concrete is a heterogeneous multiphase composite material. There are a large number of pores, microcracks and micropores between the materials of synthetic concrete, and the microcracks and micropores between the materials are random. At the same time, the solid particles of synthetic concrete and hardened cement mortar have significant differences in mechanical properties such as strength, strain, and elastic modulus. These differences in mechanical properties determine the complexity, variability, and discreteness of concrete materials.

Figures 8-10 illustrate the stress-strain curves of the HPC under coupled various loading rates after high-temperature treatments of $300{ }^{\circ} \mathrm{C}$.

For the HPC C30 (Figure 8), at the loading rate of $84.5 \mathrm{~S}^{-1}$ the stress increases with the increase in the strain. At a strain value of approximately 0.0075 , the stress reaches its peak, which affects the compressive strength of the specimen, which is approximately $38 \mathrm{Mpa}$. Thus, at the loading rate of $84.5 \mathrm{~S}^{-1}$ the loading rate does not significantly influence the compressive strength of the HPC C30. At the loading rate of $92.1 \mathrm{~S}^{-1}$, the peak stress is about $45 \mathrm{Mpa}$ when the strain is 0.0042 . For the loading rate of $139.7 \mathrm{~S}^{-1}$, the peak stress is about $70 \mathrm{Mpa}$ when the strain is 0.005 . This indicates that a higher loading rate can significantly influence the compressive stress of the HPC C30. In addition, the strains are different for the HPC C30 when stress level reach their peak at different loading rates. 
Figures 9 and 10 indicate the same conclusion: the higher loading rate significantly influences the compressive strength, while the stress levels reach their peaks at different strains for the same kind of HPC.

Thus, it can be seen from the stress-strain curves of the specimens that the dynamic compressive strength of the concrete specimens increase with the increase in the strain rate at the same temperature of $300^{\circ} \mathrm{C}$ for all three types of HPC-i.e., C30, C40, and C50.

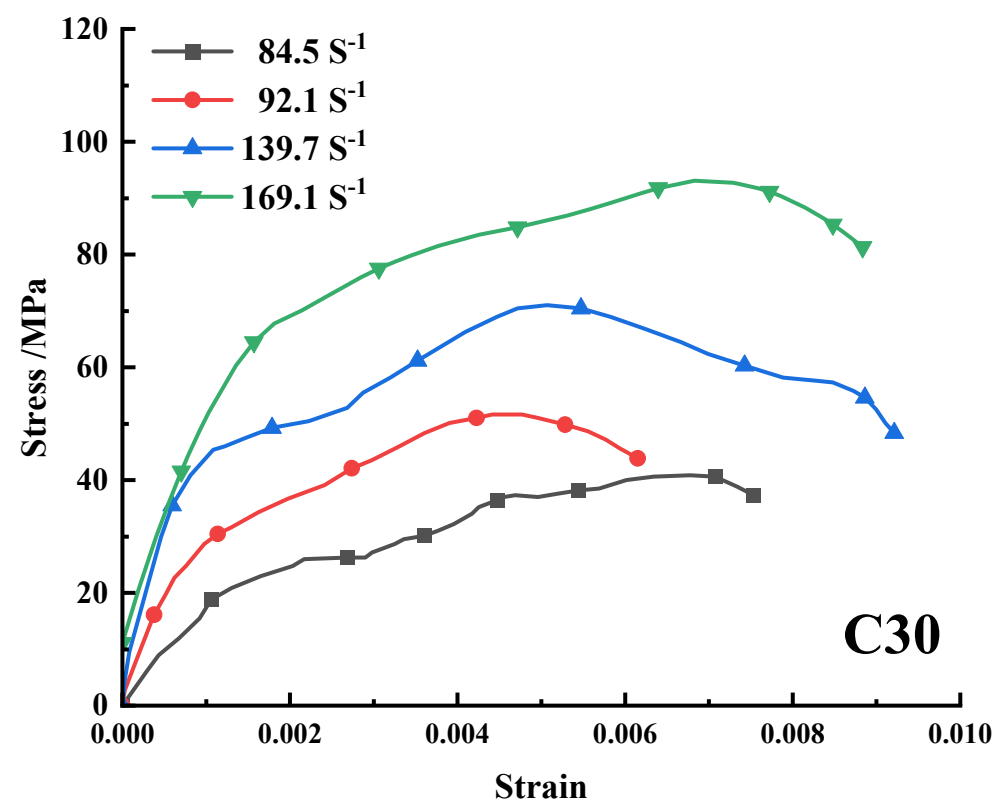

Figure 8. Stress-strain curves for HPC (C30) under various loading rates at a high temperature of $300{ }^{\circ} \mathrm{C}$.

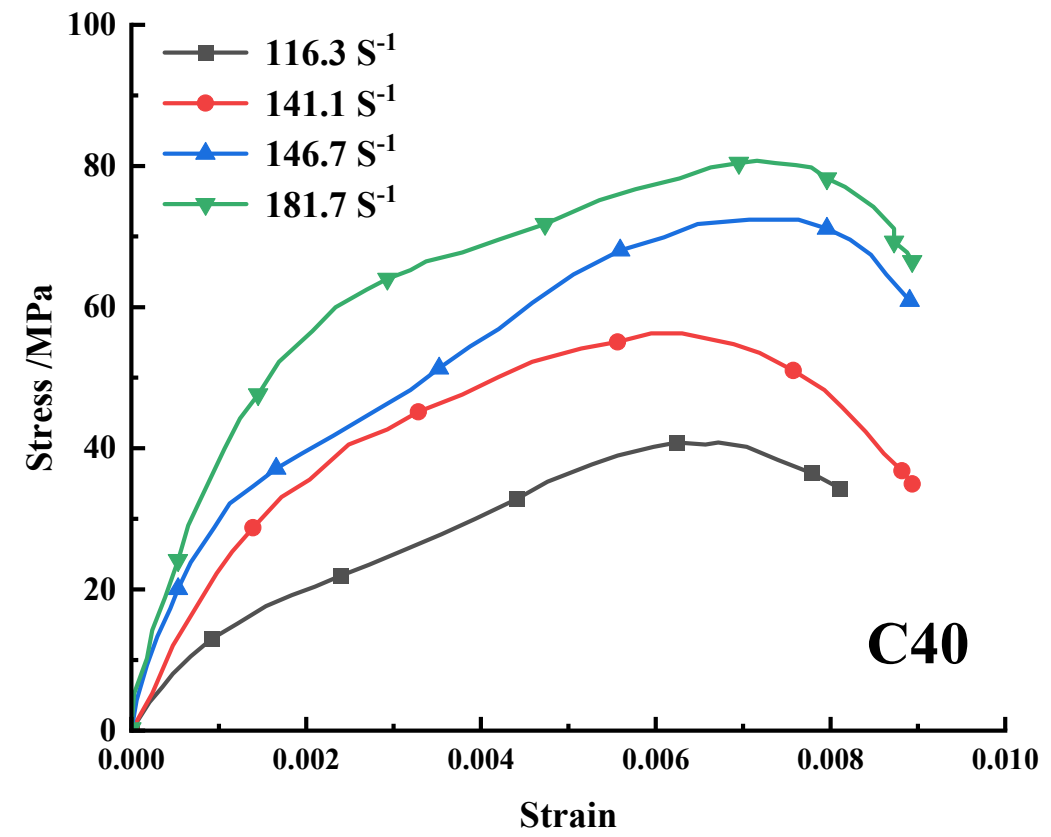

Figure 9. Stress-strain curves for HPC (C40) under various loading rates at a high temperature of $300{ }^{\circ} \mathrm{C}$. 


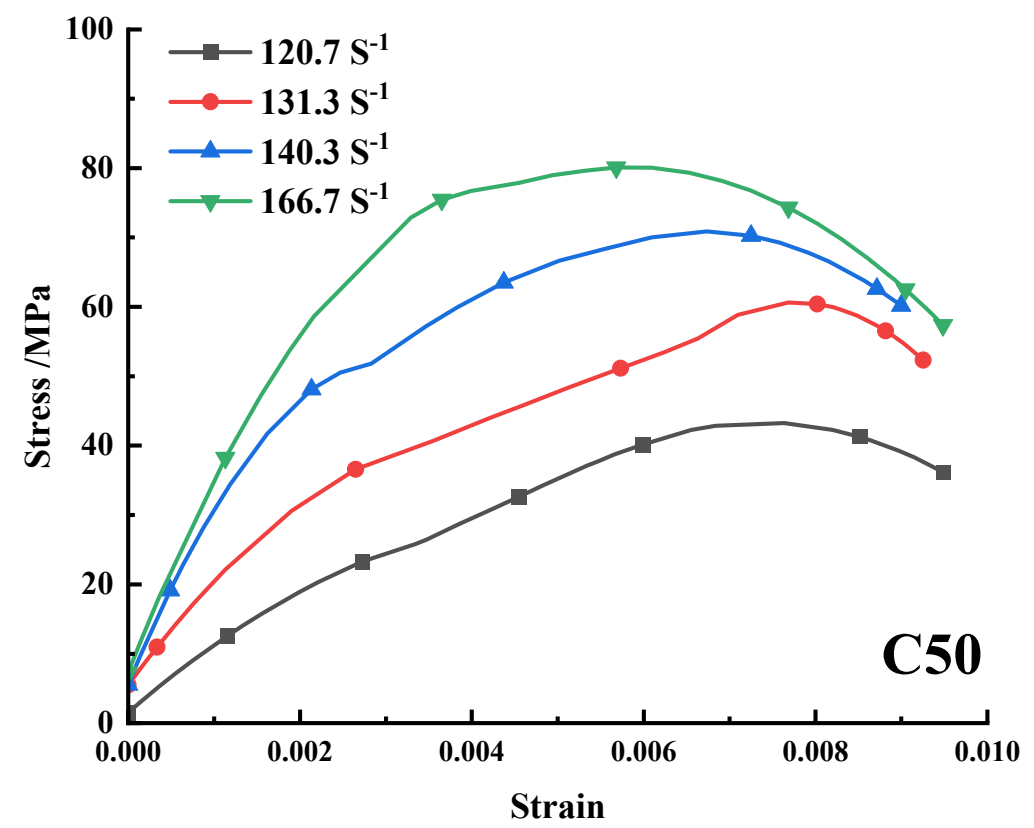

Figure 10. Stress-strain curves for HPC (C50) under various loading rates with a high temperature of $300{ }^{\circ} \mathrm{C}$.

\subsection{Effect of the High Temperature on Dynamic HPC Strength}

Figures 11-13 illustrate the dynamic compressive strength curves of the HPC under the bullet impact air pressure from 0.4 MPa to $1.2 \mathrm{MPa}$.

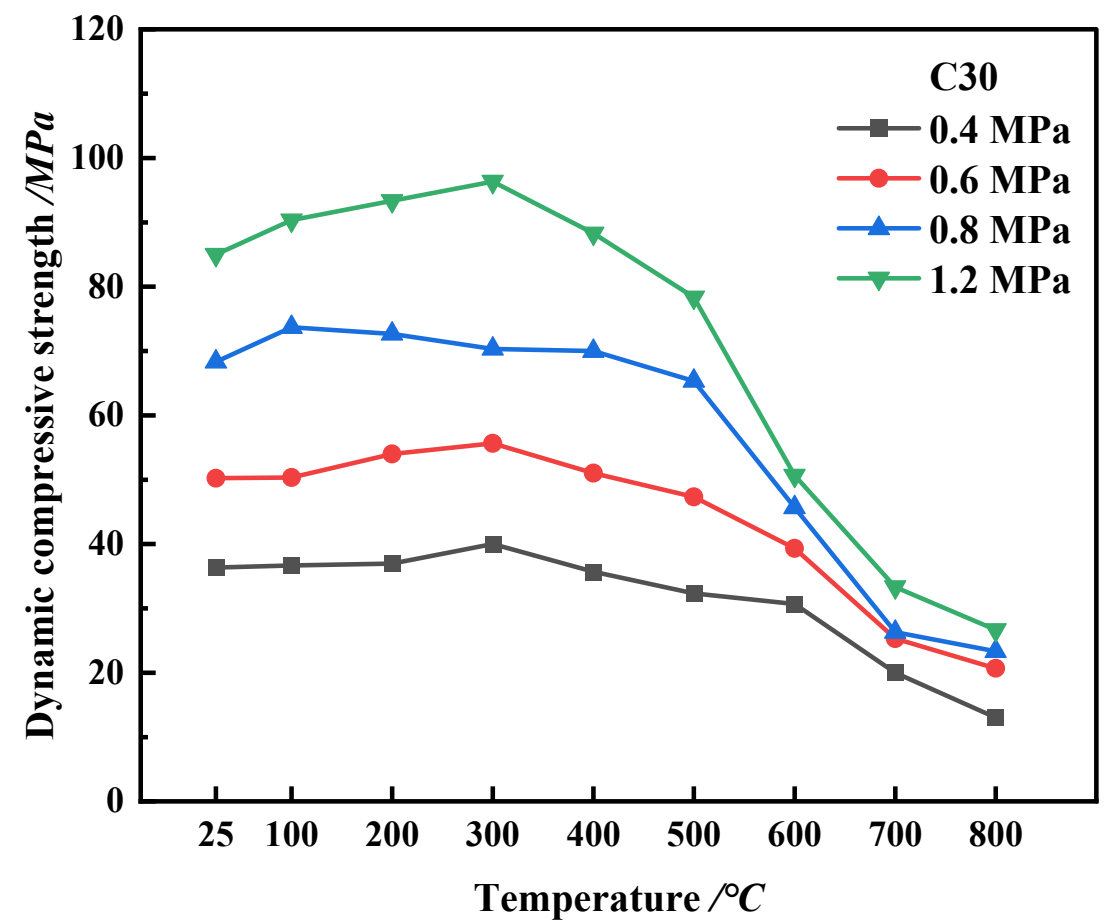

Figure 11. Dynamic compressive strength curves of concrete with grade C30. 


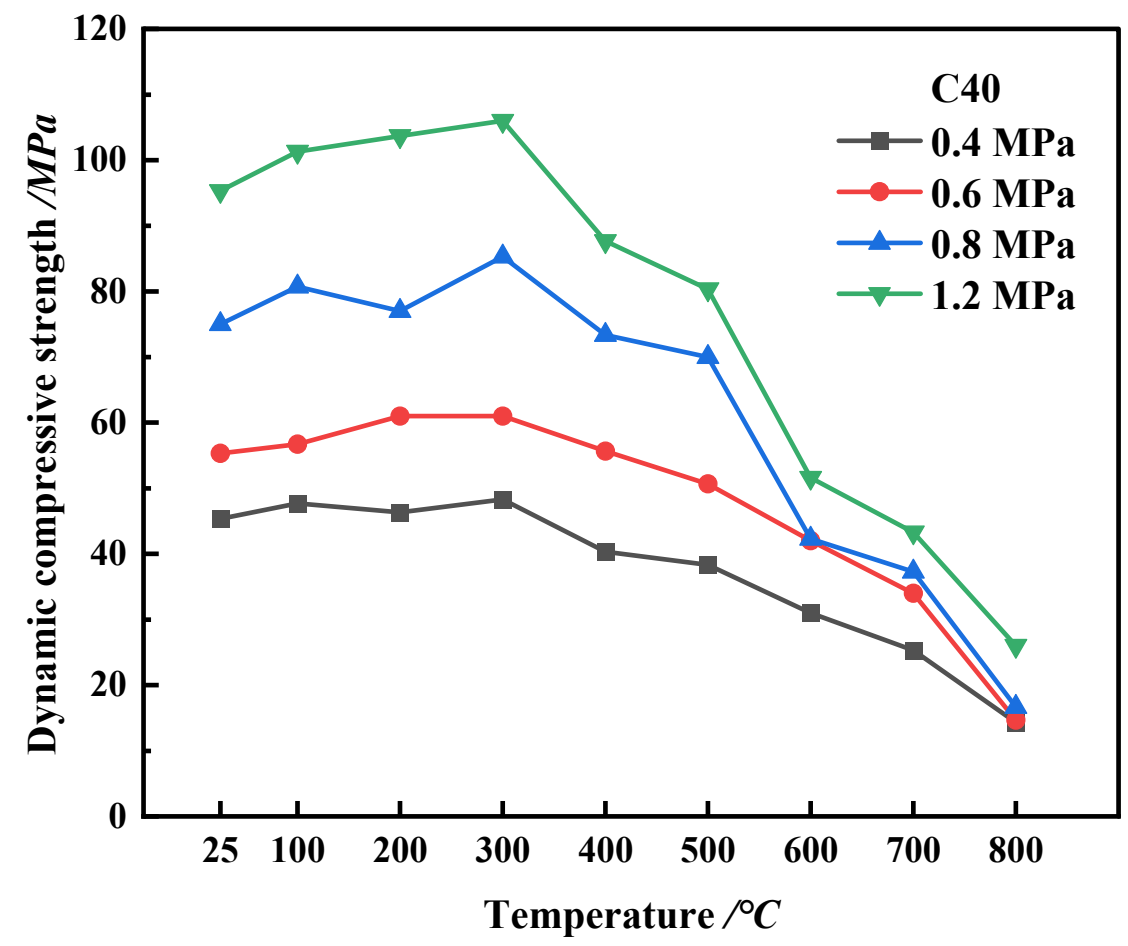

Figure 12. Dynamic compressive strength curves of concrete with grade C40.

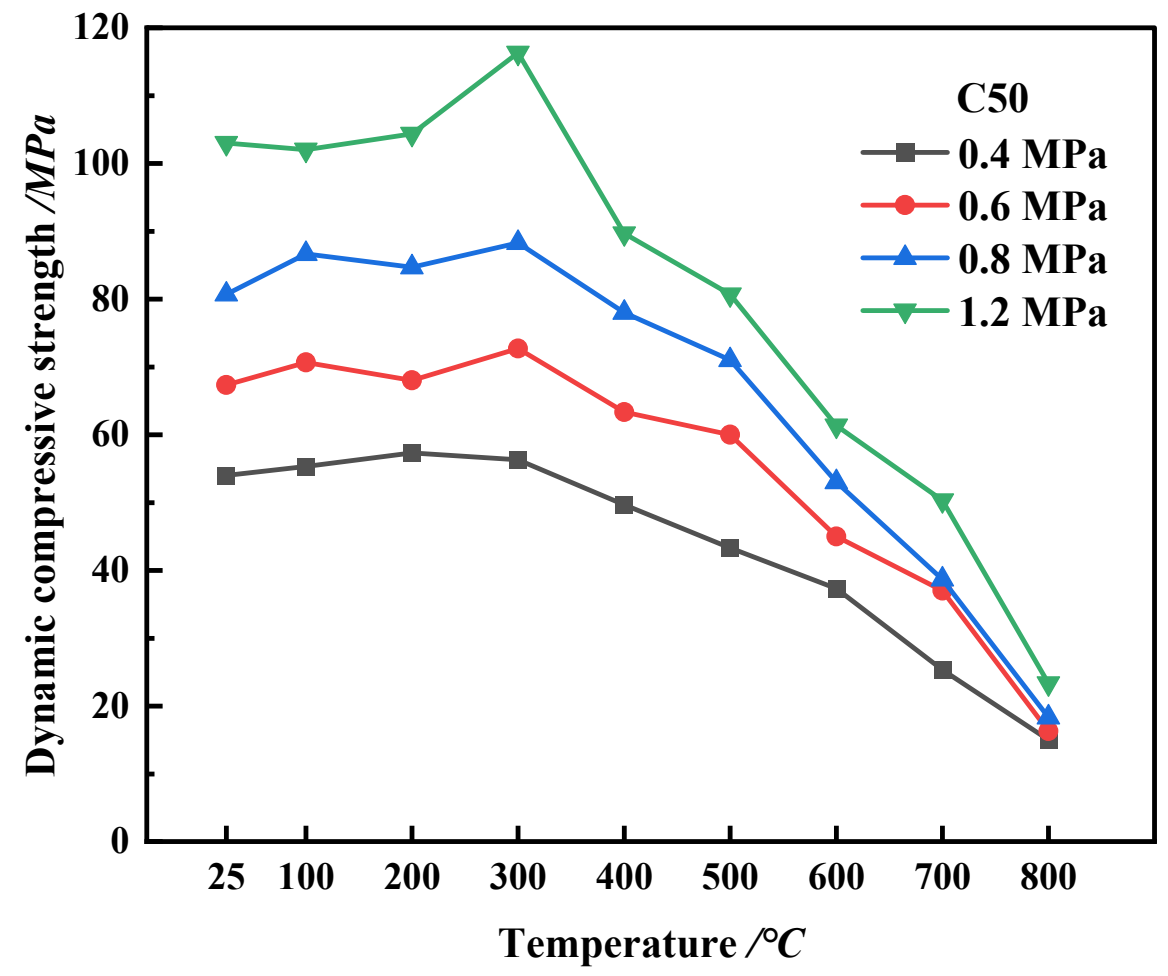

Figure 13. Dynamic compressive strength curves of concrete with grade C50.

When the temperature of the specimen is below $300{ }^{\circ} \mathrm{C}$, these results indicate that the dynamic compressive strength would increase with the rise in loading rate and reach a peak when the temperature approaches $300{ }^{\circ} \mathrm{C}$. Under the same temperature condition, the dynamic peak stress of the low-strength HPC (C30) does not change much with the increase in temperature. When the loading rate is $0.6 \mathrm{MPa}$ or $0.8 \mathrm{MPa}$, there are fluctuations. However, when the temperature is above $300{ }^{\circ} \mathrm{C}$, the dynamic compressive strength 
rapidly decreases. According to the trend across all test results, the dynamic compressive strengths of the HPC specimens show a trend of first increasing and then decreasing. The obtained results agree well with those well documented in the literature in terms of the compressive increasing and decreasing trend at various loading rates and after different high-temperature treatments $[4,6,7,58,59]$.

\section{Conclusions}

In this study, polypropylene fiber-reinforced high-performance concrete (HPC) was made using local materials in Kunming, Yunnan Province, China. Since high-strength HPC has been widely studied, this research focused on low-strength HPC. Three types of concrete- $\mathrm{C} 30, \mathrm{C} 40$, and $\mathrm{C} 50-$ were made and a number of HPC specimens were produced in order to test the dynamic and thermal behavior of the polypropylene fiber-reinforced concrete. The split Hopkinson pressure bar (SHPB) was employed for the dynamic tests and the principles of the SHPB were introduced in detail. An electric resistance furnace was employed to heat the samples while insulation measures for the specimens during the test were taken to maintain stable temperatures. Then, the polypropylene fiber-reinforced HPC was taken under the coupled various loading rates with different high-temperature treatments. It is concluded that the temperature significantly influences the HPC fracture patterns. During the SHPB test with the same air pressure (1.2 MPa) in the gas gun, many fractures were produced in the specimen with a $100{ }^{\circ} \mathrm{C}$ temperature treatment. However, it was not smashed into fragments. For the other specimens heated to higher temperatures from $200{ }^{\circ} \mathrm{C}$ to $800{ }^{\circ} \mathrm{C}$, the specimens were smashed into fragments. The main reason for this is that the melting point of the polypropylene fiber is $165^{\circ} \mathrm{C}$.

It can be seen from the stress-strain curves of the specimens that the dynamic compressive strength of the concrete specimens increase with the increase in the strain rate at the same temperature.

The temperature can influence the HPC strength. At temperatures lower than $300^{\circ} \mathrm{C}$, the HPC's compressive strength increases with increases in temperature. At temperatures higher than $300^{\circ} \mathrm{C}$, the HPC's compressive strength decreases with increases in temperature.

Author Contributions: Conceptualization, H.A. and L.L.; methodology, H.A. and L.L.; formal analysis, H.A. and L.L.; investigation, Y.W. and L.D.; writing-original draft preparation, H.A. and Y.F.; funding acquisition, L.L. All authors have read and agreed to the published version of the manuscript.

Funding: This work was partly supported by the National Science Foundation of China (Grant no. 11862010), Research Start-Up Fund for Talent of Kunming University of Science and Technology (Grant no. KKSY201867017), Program for Innovative Research Team (in Science and Technology) in University of Yunnan Province, Funding from the Research Center for Analysis and Measurement KUST (Analytic and Testing Research Center of Yunnan, Grant number 2020T20180040), Yunnan Key Laboratory of Sino-German Blue Mining and Utilization of Special Underground Space, Guizhou Provincial Department of Education Natural Science Research Top-notch talents Project (Y[2020]041), Guizhou High-level innovative talents training project (2016-21), which are greatly appreciated.

Institutional Review Board Statement: Not applicable.

Informed Consent Statement: Not applicable.

Data Availability Statement: The data used to support the findings of this study are included within the article.

Conflicts of Interest: The authors declare that there are no conflicts of interest regarding the publication of this paper.

\section{References}

1. Mansouri, I.; Shahheidari, F.S.; Hashemi, S.M.A.; Farzampour, A. Investigation of steel fiber effects on concrete abrasion resistance. Adv. Concr. Constr. 2020, 9, 367-374.

2. Chalangaran, N.M.M. Jabbari Experimental Investigation into Sound Transmission Loss through Concrete Containing Recycled Rubber. Amirkabir J. Mech. Eng. 2019, 51, 1-3. 
3. Farzampour, A. Compressive Behavior of Concrete under Environmental Effects. In Compressive Strength of Concrete; IntechOpen: London, UK, 2019; pp. 1-14.

4. An, H.; Song, Y.; Liu, L.; Meng, X. Experimental Study of the Compressive Strengths of Basalt Fiber-Reinforced Concrete after Various High-Temperature Treatments and Cooling in Open Air and Water. Appl. Sci. 2021, 11, 8729. [CrossRef]

5. Liu, L.H.M. An Experimental study of compressive failure of concrete under static and dynamic loads. Arch. Civ. Eng. 2020, 66, 427-441. [CrossRef]

6. An, H.L. Liu Numerical Study of Dynamic Behaviors of Concrete Under Various Strain Rates. Arch. Civ. Eng. 2019, 65, 21-36. [CrossRef]

7. An, H.; Hou, S.; Liu, L. Experimental and Numerical Study of the Concrete Stress and Fracture Propagation Processes by Blast. Eng. Lett. 2019, 27, 669-675.

8. Zhang, P.; Kang, L.; Wang, J.; Guo, J.; Hu, S.; Ling, Y. Mechanical properties and explosive spalling behavior of steel-fiberreinforced concrete exposed to high temperature-A review. Appl. Sci. 2020, 10, 2324. [CrossRef]

9. Chen, B.J. Liu Residual strength of hybrid-fiber-reinforced high-strength concrete after exposure to high temperatures. Cem. Concr. Res. 2004, 34, 1065-1069. [CrossRef]

10. Ren, W.; Xu, J.; Su, H. Dynamic compressive behavior of basalt fiber reinforced concrete after exposure to elevated temperatures. Fire Mater. 2016, 40, 738-755. [CrossRef]

11. Kumar, A. The effect of stress rate and temperature on the strength of basalt and granite. Geophysics 1968, 33, 501-510. [CrossRef]

12. Bažant, Z.P.; Shang-Ping, B.; Ravindra, G. Gettu Fracture of rock: Effect of loading rate. Eng. Fract. Mech. 1993, 45, 393. [CrossRef]

13. Blanton, T. Effect of strain rates from 10-2 to $10 \mathrm{sec}-1$ in triaxial compression tests on three rocks. In International Journal of Rock Mechanics and Mining Sciences \& Geomechanics Abstracts; Elsevier: Amsterdam, The Netherlands, 1981.

14. Johnson, G.R.; Stryk, R.A.; Holmquist, T.J.; Beissel, S.R. Numerical Algorithms in A Lagrangian Hydrocode; Technical Report; Defense Technical Information Center: Virginia, FL, USA, 1997.

15. Li, X.; Lok, T.; Zhao, J. Dynamic characteristics of granite subjected to intermediate loading rate. Rock Mech. Rock Eng. 2005, 38, 21-39. [CrossRef]

16. Kolsky, H. Stress Waves in Solids; Courier Corporation: North Chelmsford, MA, USA, 1963; Volume 1098.

17. Tedesco, J.; Hughes, M.; Ross, C. Numerical simulation of high strain rate concrete compression tests. Comput. Struct. 1994, 51, 65-77. [CrossRef]

18. Gálvez, F.; Rodríguez, J.; Sánchez, V. Tensile strength measurements of ceramic materials at high rates of strain. Le J. De Phys. IV 1997, 7, C3-151-C3-156. [CrossRef]

19. Sukontasukkul, P.; Nimityongskul, P.; Mindess, S. Effect of loading rate on damage of concrete. Cem. Concr. Res. 2004, 34, 2127-2134. [CrossRef]

20. Zhao, J. Applicability of Mohr-Coulomb and Hoek—Brown strength criteria to the dynamic strength of brittle rock. Int. J. Rock Mech. Min. Sci. 2000, 37, 1115-1121. [CrossRef]

21. Zhang, Z.X.; Kou, S.Q.; Jiang, L.G.; Lindqvist, P.A. Effects of loading rate on rock fracture: Fracture characteristics and energy partitioning. Int. J. Rock Mech. Min. Sci. 2000, 37, 745-762. [CrossRef]

22. Dai, F.; Huang, S.; Xia, K.; Tan, Z. Some fundamental issues in dynamic compression and tension tests of rocks using split Hopkinson pressure bar. Rock Mech. Rock Eng. 2010, 43, 657-666. [CrossRef]

23. Dai, F.; Xia, K.; Zheng, H.; Wang, Y.X. Determination of dynamic rock mode-I fracture parameters using cracked chevron notched semi-circular bend specimen. Eng. Fract. Mech. 2011, 78, 2633-2644. [CrossRef]

24. Eissa, E.A. Kazi Relation between static and dynamic Young's moduli of rocks. In International Journal of Rock Mechanics and Mining Sciences \& Geomechanics Abstracts; Elsevier: Amsterdam, The Netherlands, 1988.

25. Mahanta, B.; Tripathy, A.; Vishal, V.; Singh, T.N.; Ranjith, P.G. Effects of strain rate on fracture toughness and energy release rate of gas shales. Eng. Geol. 2017, 218, 39-49. [CrossRef]

26. Zhang, Z. Laboratory Studies of Dynamic Rock Fracture and in-Situ Measurements of Cutter Forces for a Boring Machine. Doctoral Dissertation, Luleå Tekniska Universitet, Luleå, Sweden, 2001.

27. Li, X.B.; Yin, T.B.; Zhou, Z.L.; Hong, L.; Gao, K. Study of dynamic properties of siltstone under coupling effects of temperature and pressure. Chin. J. Rock Mech. Eng. 2010, 29, 2377-2384.

28. Yin, T.B.; Li, X.B.; Ye, Z.Y.; Gong, F.Q.; Zhou, Z.L. Energy dissipation of rock fracture under thermo-mechanical coupling and dynamic disturbances. Chin. J. Rock Mech. Eng. 2013, 32, 1197-1202.

29. Savastano, H., Jr.; Santos, S.F.; Radonjic, M.; Soboyejo, W.O. Fracture and fatigue of natural fiber-reinforced cementitious composites. Cem. Concr. Compos. 2009, 31, 232-243. [CrossRef]

30. Bhat, T.; Chevali, V.; Liu, X.; Feih, S.; Mouritz, A.P. Fire structural resistance of basalt fibre composite. Compos. Part A Appl. Sci. Manuf. 2015, 71, 107-115. [CrossRef]

31. Sim, J.; Park, C.D.; Moon, Y. Characteristics of basalt fiber as a strengthening material for concrete structures. Compos. Part B Eng. 2005, 36, 504-512. [CrossRef]

32. Noushini, A.; Samali, B.; Vessalas, K. Effect of polyvinyl alcohol (PVA) fibre on dynamic and material properties of fibre reinforced concrete. Constr. Build. Mater. 2013, 49, 374-383. [CrossRef]

33. Arisoy, B.; $\mathrm{Wu}, \mathrm{H}$.C. Material characteristics of high performance lightweight concrete reinforced with PVA. Constr. Build. Mater. 2008, 22, 635-645. [CrossRef] 
34. $\mathrm{Wu}, \mathrm{H} . ; \mathrm{Lin}, \mathrm{X} . ; \mathrm{Zhou}, \mathrm{A}$. A review of mechanical properties of fibre reinforced concrete at elevated temperatures. Cem. Concr. Res. 2020, 135, 106117. [CrossRef]

35. Ríos, J.D.; Leiva, C.; Ariza, M.P.; Seitl, S.; Cifuentes, H. Analysis of the tensile fracture properties of ultra-high-strength fiberreinforced concrete with different types of steel fibers by X-ray tomography. Mater. Des. 2019, 165, 107582. [CrossRef]

36. Zheng, W.; Luo, B.; Lu, S. Compressive and tensile strengths of reactive powder concrete with hybrid fibres at elevated temperatures. Rev. Romana De Mater.-Rom. J. Mater. 2014, 44, 36-45.

37. Schneider, K.; Michel, A.; Liebscher, M.; Terreri, L.; Hempel, S.; Mechtcherine, V. Mineral-impregnated carbon fibre reinforcement for high temperature resistance of thin-walled concrete structures. Cem. Concr. Compos. 2019, 97, 68-77. [CrossRef]

38. Goldfeld, Y.; Rabinovitch, O.; Fishbain, B.; Quadflieg, T.; Gries, T. Sensory carbon fiber based textile-reinforced concrete for smart structures. J. Intell. Mater. Syst. Struct. 2016, 164, 273-282. [CrossRef]

39. Kang, S.T.; Choi, J.I.; Koh, K.T.; Lee, K.S.; Lee, B.Y. Hybrid effects of steel fiber and microfiber on the tensile behavior of ultra-high performance concrete. Compos. Struct. 2016, 145, 37-42. [CrossRef]

40. Larisa, U.; Solbon, L.; Sergei, B. Fiber-reinforced Concrete with Mineral Fibers and Nanosilica. Procedia Eng. 2017, 195, 147-154. [CrossRef]

41. Khan, M.; Ali, M. Use of glass and nylon fibers in concrete for controlling early age micro cracking in bridge decks. Constr. Build. Mater. 2016, 125, 800-808. [CrossRef]

42. Solhmirzaei, R.; Kodur, V.K.R. Modeling the response of ultra high performance fiber reinforced concrete beams. Procedia Eng. 2017, 210, 211-219. [CrossRef]

43. Yang, L.; Lin, X.; Gravina, R.J. Evaluation of dynamic increase factor models for steel fibre reinforced concrete. Constr. Build. Mater. 2018, 190, 632-644. [CrossRef]

44. Yang, L.; Lin, X.; Li, H.; Gravina, R.J. A new constitutive model for steel fibre reinforced concrete subjected to dynamic loads. Compos. Struct. 2019, 221, 110849. [CrossRef]

45. Ma, Q.; Guo, R.; Zhao, Z.; Lin, Z.; He, K. Mechanical properties of concrete at high temperature-A review. Constr. Build. Mater. 2015, 93, 371-383. [CrossRef]

46. Jyotsna Devi, P.; Srinivasa Rao, K. Compressive behaviour of steel fibre reinforced concrete at high temperatures. Indian Concr. J. 2015, 89, 21-31.

47. Kazmi, S.M.S.; Munir, M.J.; Wu, Y.F.; Patnaikuni, I.; Zhou, Y.; Xing, F. Axial stress-strain behavior of macro-synthetic fiber reinforced recycled aggregate concrete. Cem. Concr. Compos. 2019, 97, 341-356. [CrossRef]

48. Kazmi, S.M.S.; Munir, M.J.; Wu, Y.F.; Patnaikuni, I. Effect of macro-synthetic fibers on the fracture energy and mechanical behavior of recycled aggregate concrete. Constr. Build. Mater. 2018, 189, 857-868. [CrossRef]

49. Kaufmann, W. Material characterisation of macro synthetic fibre reinforced concrete. Cem. Concr. Compos. 2017, 84, 124-133.

50. Mindeguia, J.C.; Pimienta, P.; Noumowé, A.; Kanema, M. Temperature, pore pressure and mass variation of concrete subjected to high temperature-Experimental and numerical discussion on spalling risk. Cem. Concr. Res. 2010, 40, 477-487. [CrossRef]

51. Bangi, M.R.T. Horiguchi Pore pressure development in hybrid fibre-reinforced high strength concrete at elevated temperatures. Cem. Concr. Res. 2011, 41, 1150-1156. [CrossRef]

52. Ministry of Housing and Urban-Rural Construction of the People's Republic of China. Specification for Mix Proportion Design of Ordinary Concrete JGJ55-2011. Industrial Standard of the People's Republic of China 2011.12; Ministry of Housing and Urban-Rural Construction of the People's Republic of China: Beijing, China, 2011.

53. Ministry of Housing and Urban-Rural Construction of the People's Republic of China. Standard for Test Method of Mechanical Properties on Ordinary Concrete; The State Standard of the People's Republic of China: Beijing, China, June 2003.

54. Association of Senior Technologists of Tsinghua University. Technical Spcification for Application of High Performance Concrete; China Science and Technology Press: Beijing, China, 2006.

55. Han, Z.G. On the use of SHPB techniques to determine the dynamic behavior of materials in the range of small strains. Int. J. Solids Struct. 1996, 33, 3363-3375.

56. Follansbee, P.S.; Frantz, C. Wave Propagation in the Split Hopkinson Pressure Bar. J. Eng. Mater. Technol. 1983, 105, 61-66. [CrossRef]

57. An, H.; Zeng, T.; Zhang, Z.; Liu, L. Experimental Study of the Rock Mechanism under Coupled High Temperatures and Dynamic Loads. Adv. Civ. Eng. 2020, 2020, 8866621. [CrossRef]

58. Farzampour, A. Temperature and humidity effects on behavior of grouts. Adv. Concr. Constr. 2017, 5, 659-669. [CrossRef]

59. Chalangaran, N.; Farzampour, A.; Paslar, N. Nano Silica and Metakaolin Effects on the Behavior of Concrete Containing Rubber Crumbs. CivilEng 2020, 1, 264-274. [CrossRef] 